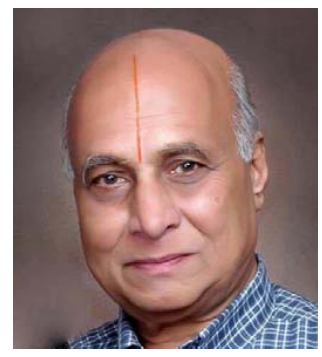

T. S. Seshadri

(1932-2015)

Tirumale Seshachar Seshadri, a veteran geologist of the Geological Survey of India (GSI) passed away at the age of 83 years at his residence in Bangalore (Bengaluru) leaving behind his wife Mrs. Padmasani and two sons T.S. Giridhar and T.S. Sridhar. T.S. Seshadri was well known among his contemporaries in GSI as a founder of the Training Institute at Chitradurga from where the UPSC candidates selected as geologists in GSI received the first training module in geological mapping of the granite-greenstone terrain around Chitradurga. He was very popular among the officers and staff of GSI because of his affable nature. He was very pious, disciplined and always health-conscious through regular regimes of yoga. He learnt yoga under the guru Omkar Master in Bangalore and for a few years he taught yoga classes on TV channels of Bangalore. He maintained frequent contacts with his colleagues and their families even after his retirement from GSI. He encouraged younger generations to do excellent work in field geology. He was also a good sportsman.

Seshadri obtained M.Sc degree in Geology from Bangalore University in 1955. He joined GSI on 20.4.1956 at Kolkata and later became Assistant Geologist and Geologist at Madras (Chennai). He was deputed from there to Neyveli Lignite Corporation and Salem Steel Plant. During his stay in Tamil Nadu, he carried out systematic geological mapping of the high-grade terrain in Madurai district. He was promoted as Senior Geologist and posted to Mysore Circle, Bangalore from where he carried out systematic mapping and exploration of Chitradurga sulphide belt. His mineral investigation camp on Medehalli road, Chitradurga was utilized initially to train the new recruits to GSI in mineral exploration and then to train in geological mapping of the Archaean granite-greenstone terrain around Chitradurga. He took pains to scan the terrain to select the best outcrops for the benefit of the trainees. Thus, Chitradurga terrain has emerged as one of the type areas in Dharwar craton for studying nearly 900 million years of the Earth's geological history from ca $3300 \mathrm{Ma}$ to ca. $2400 \mathrm{Ma}$ covering Sargur Group, Peninsular Gneiss, Dharwar Supergroup and Chitradurga Granite, which are well exposed and easily accessible for over $30 \mathrm{~km}$ in ENE-WSW direction from Ghattihosahalli to Nannivala. His training camp was converted into Regional Training Institute for Southern Region and then became part of the all-India GSI Training Institute started in 1976 as one of the six satellite training camps in India. As on date nearly 4000 geoscientists of the country and other countries too, have been trained in this classical terrain. As a mark of tribute to his services, the lecture hall in Chitradurga Training Centre is named as "T.S. SESHADRI LECTURE HALL". Seshadri used all his ingenuity to convince the district and state authorities in securing 12 acres of prime land along the NH-4 by-pass road at Chitradurga to house the Training Centre. The Centre has a well planned campus with all the necessary facilities for accommodating 30 to 40 trainees at a time. The faculty members who worked with him always remember his insistence on punctuality and discipline.

Seshadri later became the Director of DORIS Division in Kolkata and Deputy Director General in the Airborne Mineral Surveys and Exploration Wing of GSI, Bangalore before retirement on 31.05.1990. With his demise the geological community has lost a lovable mentor and a yoga master. We pray to the almighty to bestow peace to the departed soul and courage to the bereaved family.

\section{Geological Survey of India} Bangalore
H.S.M. PRAKASH 